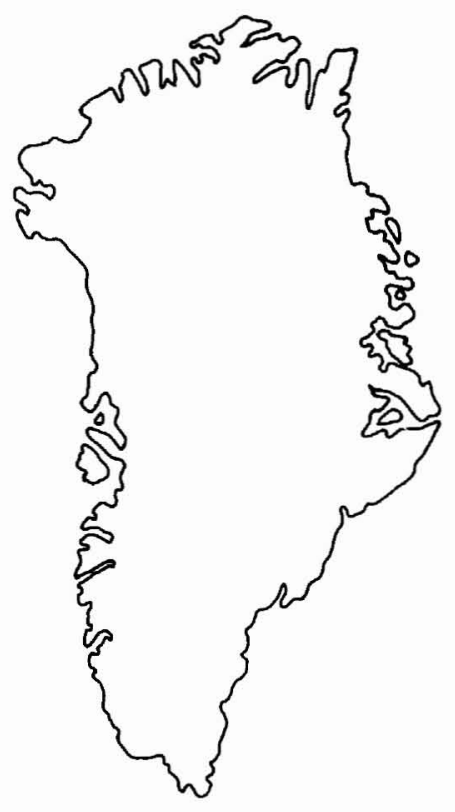

\title{
Chitinozoans from Ordovician and Silurian shelf and slope sequences in North Greenland
}

\author{
Yngve Grahn and Henrik Nøhr-Hansen
}

\begin{abstract}
This first study on chitinozoans from Greenland has revealed representatives of twenty-two chitinozoan species recovered from Ordovician and Silurian beds in North Greenland. The Ordovician faunas are similar to those described from North America, while the Silurian faunas are more similar to those of Baltoscandia. Four distinct assemblages can be separated between Maysvillian - early Gamachian and Ludlow. The chitinozoan biostratigraphy is in agreement with that of the graptolites but differs from the conodont biostratigraphy.

Y. G., Sveriges Geologiska Undersökning, Box 670, S-751 28 Uppsala, Sweden. Present address: Petrobras, Ilha do Fundao, Cidade Universitaria Quadra 7, Sala 1108A, 21910 Rio de Janeiro, R.J. Brasil.

H. N.-H., Geological Survey of Greenland, Øster Voldgade 10, DK-1350 Copenhagen K, Denmark.
\end{abstract}

During regional thermal maturity evaluation studies of Lower Palaeozoic potential source rocks from North Greenland (Christiansen et al., 1985, 1987; Christiansen \& Nøhr-Hansen, 1989) chitinozoans were recorded from about one hundred palynological slides (NøhrHansen, 1989). This preliminary paper is the first on chitinozoans from Greenland; it is based on 26 Ordovician samples from 10 localities and 64 Silurian samples from 40 localities (fig. 1). The Ordovician samples are recovered from shelf carbonates of the Steensby Gletscher, Kap Jackson (Troedsson Cliff Member), Cape Calhoun, and Aleqatsiaq Fjord Formations (fig. 2, Peel \& Hurst, 1980; Smith et al., 1989). The Silurian samples represent shales from slope environments and have been recovered from the Cape Schuchert, Wulff Land (including Thors Fjord Member) and Lafayette Bugt Formations (fig. 2, Hurst, 1980; Hurst \& Surlyk, 1982; Larsen \& Escher, 1985).

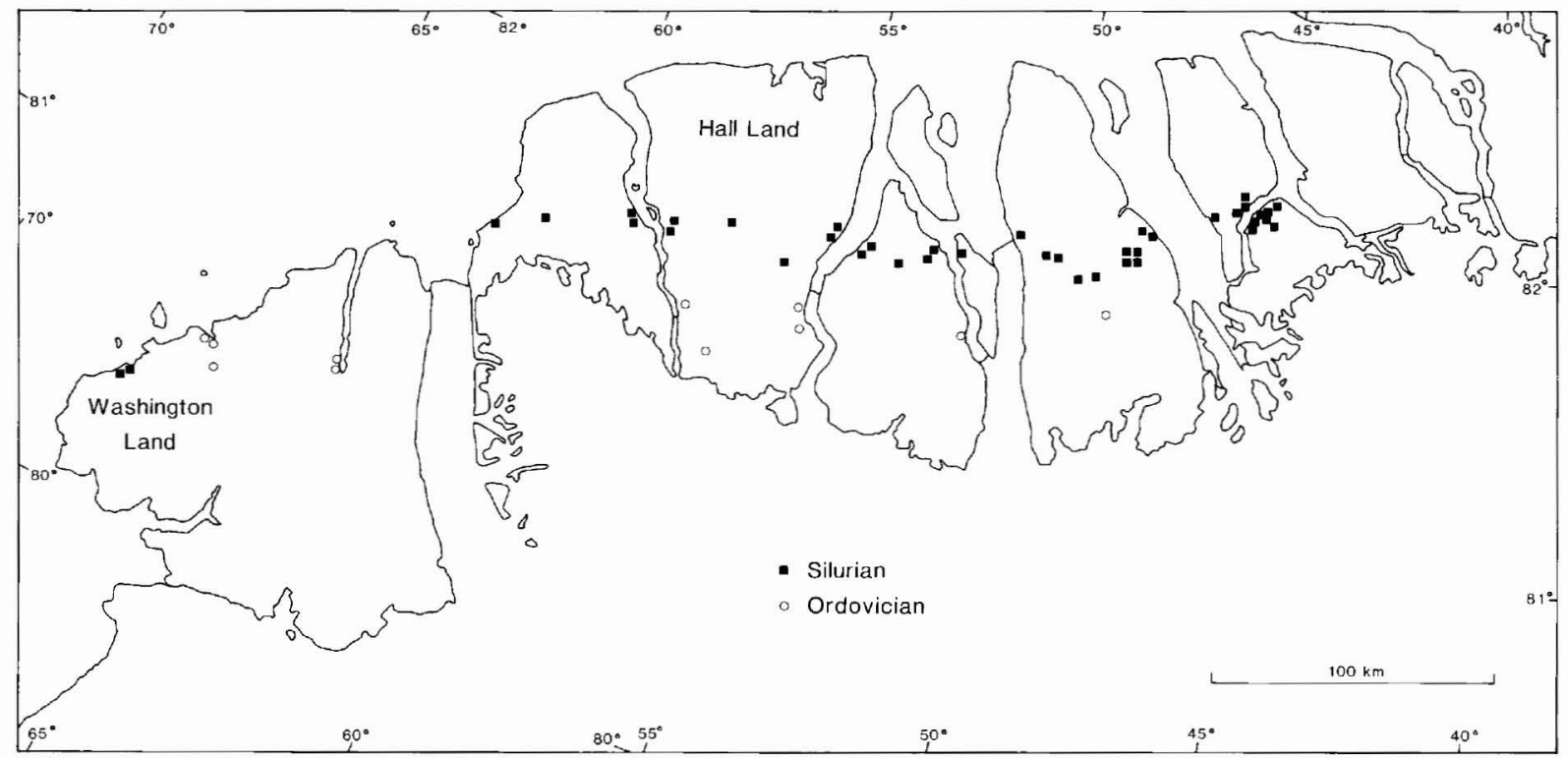

Fig. 1. Ordovician and Silurian chitinozoan sample localities in North Greenland. 


\section{Methods and material}

One hundred and twenty-six samples from Ordovician and Silurian strata in North Greenland were investigated. Ninety of these samples yielded chitinozoans. The samples were treated following standard palynological methods and sieved on $10 \mu \mathrm{m}$ nylon mesh. Most of the samples yielded only a few chitinozoan specimens, and the diversity is low (1-5 species/sample). All chitinozoans show some degree of distortion. Micrographs were taken of selected gold-coated specimens with a JEOL JSM-35 at $15 \mathrm{kV}$. All illustrated specimens are kept in the type collection of the Geological Museum of the University of Copenhagen (MGUH numbers).

\section{Chitinozoan biostratigraphy}

The Ordovician and Silurian sequences from North Greenland display diagnostic chitinozoan faunas. The samples investigated yielded twenty-two chitinozoan taxa, seven of which are classified in open nomenclature. The biostratigraphic significance of these taxa and a conceivable correlation of the different formations are shown in fig. 2. The Ordovician chitinozoans show striking similarities to those of North America, while the Silurian faunas are more similar to those of Baltoscandia.

In the Steensby Gletscher Formation only Conochitina sp. 1 (fig. 3F) has been recovered, and this species has no restricted age significance. The rest of the samples have yielded chitinozoan faunas which can be grouped into four distinct assemblages.

The oldest distinct assemblage occurs in the upper part of the Troedsson Cliff Member of the Kap Jackson Formation, the Cape Calhoun Formation and the lower part of the Aleqatsiaq Fjord Formation (Newman Bugt Member). It is a characteristic Richmondian - early Gamachian fauna with strong similarities to Anticosti Island, eastern Canada (Achab, 1977a, b, 1978). Diagnostic species, such as Hercochitina crickmayi? (fig. 3I) and Tanuchitina anticostiensis (fig. $3 \mathrm{H}$ ), are present. The presence of Angochitina capillata sensu stricto (fig. 3A) in the lower part of the Troedsson Cliff Member suggests that this part of the sequence might be as old as Shermanian in age, but considering the stratigraphic position it is more likely to be Maysvillian in age. Other species are Conochitina of. C. cactacea (fig. 3B), Conochitina aff. $C$. dolosa (fig. 3C), Conochitina elegans (fig. 3D), Conochitina micracantha (fig. 3E), Conochitina sp. 1 (fig. 3F), Conochitina sp. 2 (fig. 3G), Desmochitina complanata (fig. 3J) and Hercochitina cf. $H$. crickmayi (fig. 3K). According to Smith et al. (in press),

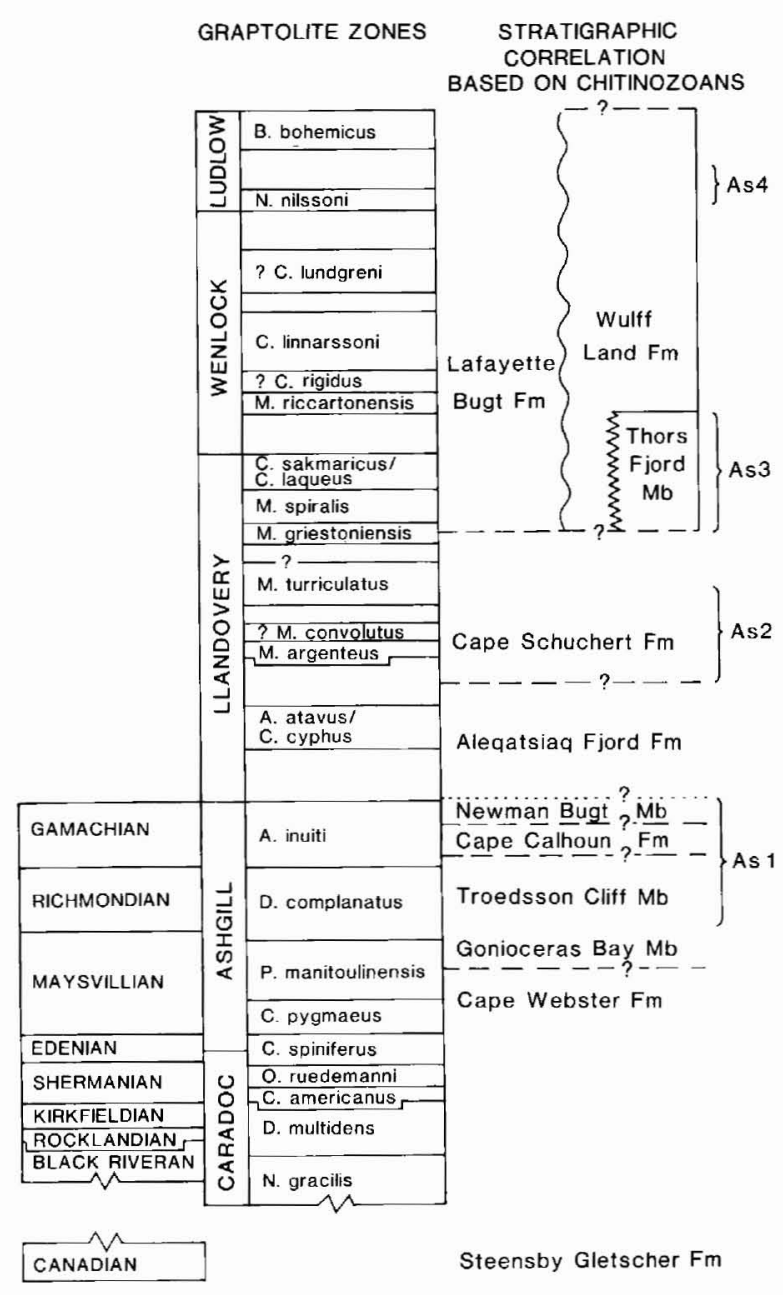

Fig. 2. Biostratigraphic correlation of the Ordovician and Silurian strata strata from North Greenland, based on the studied chitinozoans and Ordovician graptolite zones (Ross et al., 1982) and Silurian graptolite zones (Bjerreskov, 1986). The four chitinozoan assemblages are marked As1-As4.

the conodonts indicate a late Whiterockian to late Edenian age for the Troedsson Cliff Member. A closer sampling of critical sections might give an explanation of these differences. Finds of graptolites are rare in the Ordovician platform strata of North Greenland. However, the Amplexograptus inuiti Zone is represented in the lower part of the Aleqatsiaq Fjord Formation (Newman Bugt Member). This confirms a Gamachian age for this part of the sequence, which is in agreement with the chitinozoan biozonation.

The upper part of the Aleqatsiaq Fjord Formation (Kap Ammen and Store Canyon Members) seems to be barren of chitinozoans, but the conodonts indicate that the age of these beds is around the Ordovician-Silurian boundary. The oldest Silurian chitinozoan assemblage is 
found in the Cape Schuchert Formation. It consists of Conochitina iklaensis (fig. 4E) and Conochitina cf. C. edjelensis (fig. 4D). These species have been reported from middle Llandoverian strata in Baltoscandia (Nestor, 1980), and similar specimens are known from the upper part of the Gun River Formation on Anticosti Island (Achab, 1981), and the Belfast Member of the Brassfield Formation in the midcontinent U.S.A. (Grahn \& Bergström, 1985).

A distinctive Silurian assemblage in the Thors Fjord Member also dominates the samples from the Lafayette Bugt and Wulff Land Formations. The dominant species are Angochitina longicollis (fig. 4C), Eisenackitina dolioliformis (fig. 4I) and to some extent Conochitina proboscifera f. truncata (fig. 4G). The co-occurrence of these three species is diagnostic for upper Llandovery (spiralis Zone) to early Wenlock (centrifugus/murchisoni zones) beds in Baltoscandia. Associating species are Ancyrochitina ancyrea, Ancyrochitina sp. (fig. 4A) and Conochitina proboscifera $\mathrm{f}$. gracilis (fig. 4F). Samples with these two Conochitina species indicate a stratigraphic level at the Llandovery-Wenlock boundary or just above. Diagnostic chitinozoans from younger Wenlock strata have not been recovered.

A few samples from the Wulff Land Formation yielded Angochitina echinata (fig. 4B), Linochitina convexa (fig. $4 \mathrm{H}$ ) and Linochitina erratica (fig. 4J). Similar associations are known from the Ludlow in Baltoscandia (Laufeld, 1974).

The chitinozoan biostratigraphy in the Silurian is in agreement with that based on graptolites (Bjerreskov, 1986; personal communication, 1987).

\section{Remarks on taxonomy and occurrence}

Most of the chitinozoan species recovered from North Greenland have been described recently; they are therefore illustrated but not discussed. Synonyms and stratigraphical ranges are listed by Achab $(1977 \mathrm{a}, \mathrm{b})$, Jenkins (1969, 1970), Laufeld (1974), Nestor (1980), and Grahn (1982). Comments on the morphology and occurrence of chitinozoans classified in open nomenclature are given below.

\section{Ancyrochitina sp.}

Fig. 4A

Remarks. A few specimens of this species have been found in the Thors Fjord Member of the Wulff Land Formation and in the Lafayette Bugt Formation. They have a cylindrical neck and an ovoid body. The absence of complete appendices makes specific determination difficult.
Conochitina cf. C. cactacea

Fig. 3B

Remarks. Specimens of Conochitina cactacea Eisenack 1937 from the type area in Baltoscandia disappear in the lower part of the Pleurograptus linearis Zone. The average size is smaller than those from Greenland, which are more similar to populations from the Cincinnatian Sylvan Shale of the Arbuckle Mountains in Oklahoma, U.S.A. (Jenkins, 1970). The Greenland specimens are left in open nomenclature because of the differences in size and stratigraphical range.

\section{Conochitina aff. C. dolosa}

Fig. $3 \mathrm{C}$

Remarks. Specimens similar to Conochitina dolosa Laufeld, 1967 are not uncommon in Ashgillian beds from Estonia (Nõlvak, 1984) and Anticosti Island, Canada (Achab, 1977b). In Baltoscandia C. dolosa sensu stricto is restricted to early Caradocian beds (Laufeld, 1967) and is provided with a flat and broad mucro. Such a mucro has not been observed in the specimens from Greenland.

\section{Conochitina $\mathrm{cf}$. C. edjelensis}

Fig. 4D

Remarks. Conochitina edjelensis Taugourdeau, 1963 is a characteristic species of middle Llandoverian strata in south-western Europe and North Africa. Specimens similar to $C$. edjelensis have been reported from contemporaneous strata in Estonia (Nestor, 1980) and Anticosti Island, Canada (Achab, 1981). The specimens from North Greenland differ from $C$. edjelensis in having a larger size.

\section{Conochitina sp. 1}

Fig. 3F

Remarks. Specimens of Conochitina sp. 1 occur in the Steensby Gletscher Formation and in the lower part of the Troedsson Cliff Member of the Kap Jackson Formation. They have a coalescent ornamentation similar to that of Conochitina robusta Eisenack, 1959. Specimens similar to Conochitina sp. 1 are known from various middle and upper Ordovician strata. 

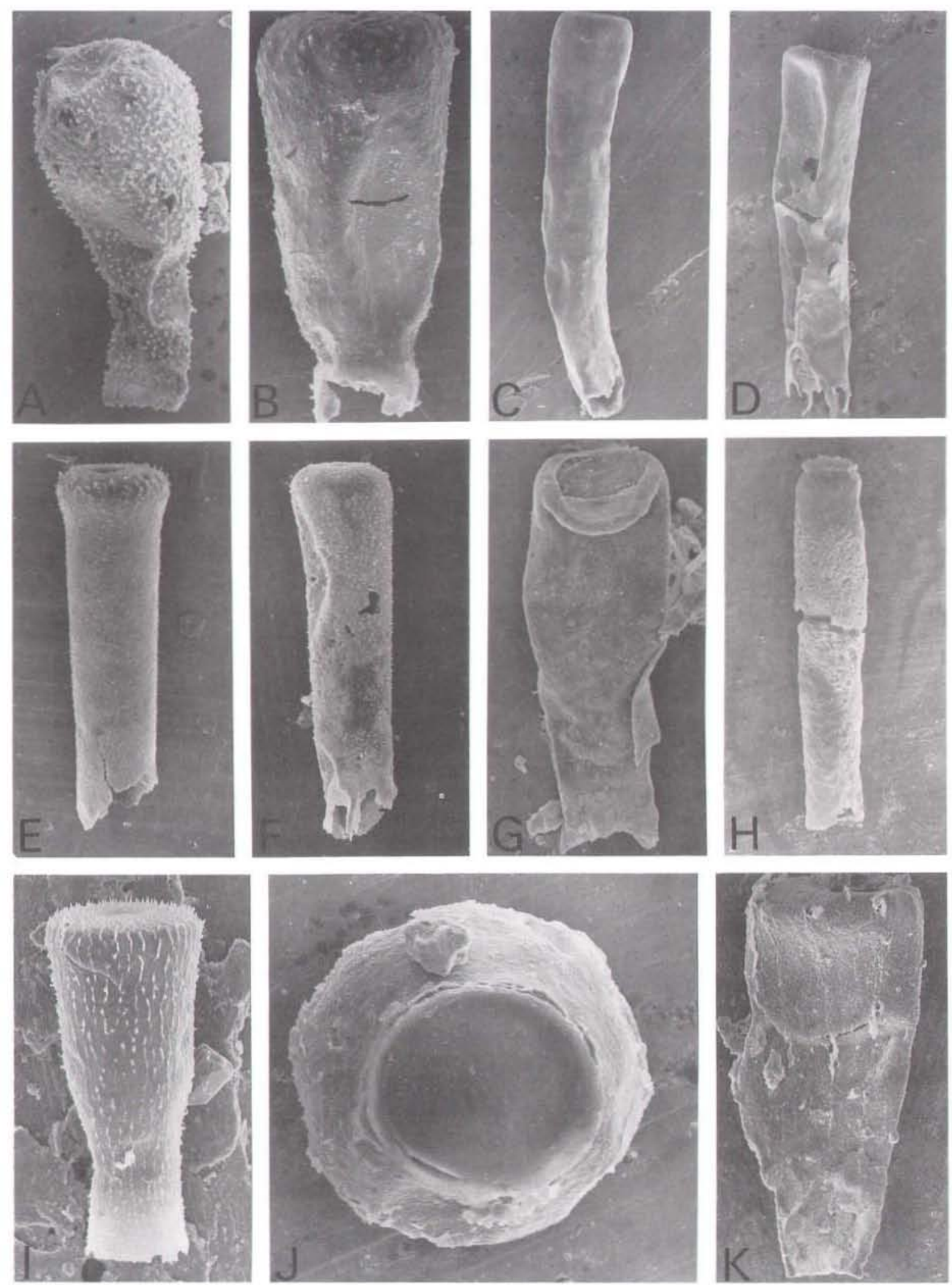


\section{Conochitina sp. 2}

Fig. 3G

Remarks. A few specimens of Conochitina sp. 2 were recovered from the Cape Calhoun and Aleqatsiaq Fjord Formations and always occur together with Tanuchitina anticostiensis. Similar specimens are described as Conochitina sp. A by Achab (1977a) and Geng et al. (1984).

\section{Hercochitina cf. H. crickmayi}

Fig. 3K

Remarks. Hercochitina cf. $H$. crickmayi differ from $H$. crickmayi? in having less pronounced longitudinal rows of spines on the vesicle wall. The distance between the different rows is also wider. Similar specimens have been reported from a boring in the Hudson Strait, Canada (M. A. Miller, personal communication, 1987).

Acknowledgements. The project was supported by the Danish Ministry of Energy through project No. EFP 83-2251-305 and the Swedish-Danish Culture Foundation (Svensk-Danska Kulturfonden). The authors thank M. Sønderholm and J. S. Peel for discussions and suggestions for improvement of the manuscript. K. Villadsen prepared the samples, B. Sikker Hansen produced the figures and M. Larsen typed the manuscript.

\section{References}

Achab, A. 1977a: Les chitinozoaires de la zone à Dicellograptus complanatus Formation de Vauréal, Ordovicien Supérieur, Ile d'Anticosti, Quebec. Can. J. Earth Sci. 14, 413425.

Achab, A. 1977b: Les chitinozoaires de la zone à Climacograptus prominens elongatus de la Formation de Vauréal (Ordovicien Supérieur), Ile d'Anticosti, Quebec. Can. J. Earth Sci. 14, 2193-2212.
Achab, A. 1978: Sur quelques chitinozoaires de la Formation de Vauréal et de la Formation de Macasty (Ordovicien Supérieur), Ile d'Anticosti, Quebec, Canada. Rev. Palaeobot. Palynol. 25, 295-314.

Achab, A. 1981: Biostratigraphie par les chitinozoaires de l'Ordovicien Supérieur - Silurien Inférieur de l'Anticosti. Résultats préliminaires. In Lespérance, P. J. (edit.) Subcommission on Silurian Stratigraphy, Ordovician-Silurian Boundary Working Group. Field Meeting, Anticosti-Gaspé, Université de Montreal 2, 143-157.

Bjerreskov, M. 1986: Silurian graptolites from N Greenland. In Hughes, C. P. \& Rickards, R. B. (edit.) Palaeoecology and biostratigraphy of graptolites. Geol. Soc. Spec. Publ. 20, 181-189.

Christiansen, F. G. \& Nøhr-Hansen, H. 1989: The Silurian shales of central and western North Greenland: evaluation of hydrocarbon source rock potential. Rapp. Gronlands geol. Unders. 143.

Christiansen, F. G., Nøhr-Hansen, H., Rolle, F. \& Wrang, P. 1985: Preliminary analysis of the hydrocarbon source rock potential of central and western North Greenland. Rapp. Grønlands geol. Unders. 126, 117-128.

Christiansen, F. G., Nøhr-Hansen, H. \& Nykjær, O. 1987: The Cambrian Henson Gletscher Formation: a mature to postmature hydrocarbon source rock sequence from North Greenland. Rapp. Grønlands geol. Unders. 133, 141-157.

Geng L., Hu Z. \& Gong L. 1984: Upper Ashgillian Chitinozoa from Renhuai, northern Guizhou. Stratigraphy and palaeontology of systematic boundaries in China. Ordovician-Silurian boundary 1, 259-266. Nanjing: Nanjing Univ. Publ. House.

Grahn, Y. 1982: Caradocian and Ashgillian Chitinozoa from the subsurface of Gotland. Sver. Geol. Unders. C 788, 66 pp.

Grahn, Y. \& Bergström, S. M. 1985: Chitinozoans from the Ordovician-Silurian boundary beds in the eastern Cincinnati region in Ohio and Kentucky. Ohio J. Sci. 85, 175-183.

Hurst, J. M. 1980: Silurian stratigraphy and facies distribution in Washington Land and western Hall Land, North Greenland. Bull. Gronnlands geol. Unders. 138, 95 pp.

Hurst, J. M. \& Surlyk, F. 1982: Stratigraphy of the Silurian turbidite sequence of North Greenland. Bull. Gronlands geol. Unders. 145, $121 \mathrm{pp}$.
Fig. 3. Ordovician Chitinozoa from North Greenland. A. Angochitina capillata Eisenack, 1937. Troedsson Cliff Member. $\times$ 313, MGUH 19477 from GGU sample 316106 .

B. Conochitina cf. C. cactacea. Troedsson Cliff Member. $\times$ 365, MGUH 19478 from GGU sample 316106.

C. Conochitina aff. C. dolosa. Troedsson Cliff Member. $\times 160$, MGUH 19479 from GGU sample 316072.

D. Conochitina elegans Eisenack, 1931. Aleqatsiaq Fjord Formation. $\times$ 160, MGUH 19480 from GGU sample 316103 .

E. Conochitina micracantha Eisenack, 1931. Troedsson Cliff Member. $\times$ 210. MGUH 19481 from GGU sample 316962 .

F. Conochitina sp. 1. Stensby Gletscher Formation. $\times 175$,
MGUH 19482 from GGU sample 316136.

G. Conochitina sp. 2. Cape Calhoun Formation. $\times 197$, MGUH 19483 from GGU sample 316098.

H. Tanuchitina anticostiensis (Achab, 1977). Troedsson Cliff Member. × 87, MGUH 19484 from GGU sample 315964.

I. Hercochitina crickmayi? Jansonius, 1964. Troedsson Cliff Member. × 263, MGUH 19485 from GGU sample 316968.

J. Desmochitina complanata Eisenack, 1932. Troedsson Cliff Member. $\times$ 547, MGUH 19486 from GGU sample 316962. K. Hercochitina $\mathrm{cf}$. H. crickmayi. Troedsson Cliff Member. $\times$ 240, MGUH 19487 from GGU sample 316072. 

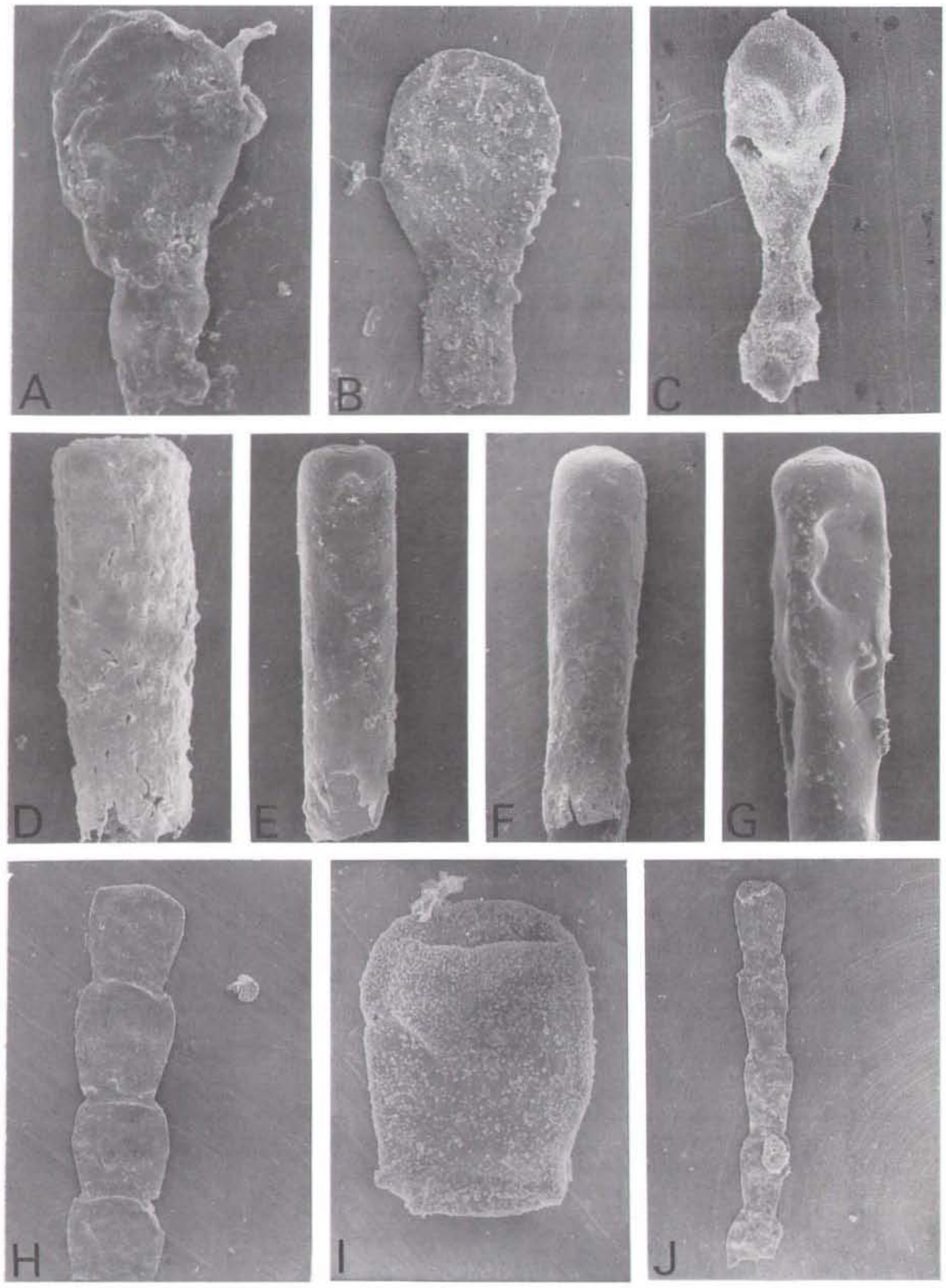
Jenkins, W. A. M. 1969: Chitinozoa from the Ordovician Viola and Fernvale Limestones of the Arbuckle Mountains, Oklahoma. Spec. Papers in Palaeontology 5, 1-44.

Jenkins, W. A. M. 1970: Chitinozoa from the Ordovocian Sylvan Shale of the Arbuckle Mountains, Oklahoma. Palaeontology 13, 261-288.

Larsen, P.-H. \& Escher, J. C. 1985: The Silurian turbidite sequences of the Peary Land Group between Newman Bugt and Victoria Fjord, western North Greenland. Rapp. Grønlands geol. Unders. 126, 47-67.

Laufeld, S. 1967: Caradocian Chitinozoa from Dalarna, Sweden. Geol. Fören. Stockh. Förh. 89, 175-349.

Laufeld, S. 1974: Silurian Chitinozoa from Gotland. Fossils and Strata 5, $130 \mathrm{pp}$.

Nestor, V. 1980: [Middle Llandoverian chitinozoans from Estonia.] Eesti NSV Teaduste Akadeemia Toimetised Geoloogia 29, 136-142. (In Russian with English summary.)
Nøhr-Hansen, H. 1989: Palynological studies of the organic matter. In Christiansen, F. G. (edit.) Petroleum geology of North Greenland. Bull. Grønlands geol. Unders. 158, 27-31. Nölvak, J. 1980: Chitinozoans in biostratigraphy of the northern East Baltic Ashgillian. A preliminary report. Acta Palaeontol. Pol. 25, 253-260.

Peel, J. S. \& Hurst, J. M. 1980: Late Ordovician and early Silurian stratigraphy of Washington Land, western North Greenland. Rapp. Grønlands geol. Unders. 100, 18-24.

Ross, R. J., Adler, F. J., Amsden, T. W. et al. 1982: The Ordovician System in the United States: correlation chart and explanatory notes. International Union of Geological Sciences Publication 12, 73 pp.

Smith, M. P., Sønderholm, M. \& Tull, S. J. 1989: The Morris Bugt Group (Middle Ordovician - Early Silurian) of North Greenland and its correlations. Rapp. Grønlands geol. Unders. 143.
Fig. 4. Silurian Chitinozoa from North Greenland.

A. Ancyrochitina sp. Lafayette Bugt Formation. $\times 343$, MGUH 19488 from GGU sample 324120.

B. Angochitina echinata Eisenack, 1931. Wulff Land Formation. $\times$ 313, MGUH 19489 from GGU sample 315950 .

C. Angochitina longicollis Eisenack, 1959. Lafayette Bugt Formation. $\times 219$, MGUH 19490 from GGU sample 316490 .

D. Conochitina cf. C. edjelensis. Cape Schuchert Formation. $\times$ 175, MGUH 19491 from GGU sample 316049.

E. Conochitina iklaensis Nestor, 1980. Cape Schuchert Formation. $\times$ 197, MGUH 19492 from GGU sample 316049 .

F. Conochitina proboscifera f. gracilis Laufeld, 1974. Lafayette
Bugt Formation. $\times$ 160, MGUH 19493 from GGU sample 316062.

G. Conochitina proboscifera f. truncata Laufeld, 1974. Lafayette Bugt Formation. × 197, MGUH 19494 from GGU sample 316062 .

H. Linochitina convexa Laufeld, 1974. Wulff Land Formation. $\times$ 175, MGUH 19495 from GGU sample 315950.

I. Eisenackitina dolioliformis Umnova, 1976. Lafayette Bugt Formation. × 313, MGUH 19496 from GGU sample 316426 . J. Linochitina erratica (Eisenack, 1931). Wulff Land Formation. $\times$ 87, MGUH 19497 from GGU sample 315950 . 